\title{
Constraints Faced By Guava Growers in Production and Marketing of Districts of Haryana State
}

\author{
Veer Sain, V. P. Luhach, V. K. Singh, Mohinder Singh Mehla and *Ved jyoti \\ Research Schloar, Senior Scientist, Senior Scientist and *Research scholar (ICG IIS Univ.) \\ Deptt. of Agricultural Economics, CCS, Haryana Agricultural University, Hisar-125004 (Haryana)
}

The present study was conducted in Hisar district, Hansi, Barwala Block, and Fatehabad district Bhuna, Fatehabad Block and Sirsa district Baraguda, Sirsa Block of Haryana which was selected purposively on basis of highest area and production under Guava cultivation. Further, Hisar, Fatehabad and Sirsa market were selected for the market study. Finally 60 growers from randomly selected two blocks from each district were selected for the present study. On the basis of the nature of the data, budgeting technique and various economic tools were used for estimation of production constraints. Major problems faced by the Guava growers in production of Guava were damage due to aberrant weather conditions, non-availability of good seedling and lack of technical knowledge. Problems faced in marketing were lack of support price, lack of market organization and non-availability of processing facilities. The study emphasized the need to develop the proper marketing and processing facilities before its cultivation is popularized on a large scale in the state.

\section{Introduction}

Guava fruit is commercially grown throughout the country. In India, production of guava is 2.27 Metric Tons with an area coverage of 0.20 million hectares (Kumar et al., 2010). In Haryana, production of guava is 0.053 Metric Tons with an area coverage of 0.007 million hectares (Anonymous, 2010).

During marketing stage, the guava producers may be faced with manifold problems which have direct bearing upon the prosperity of producers. The main marketing problems are unorganised marketing, poor post harvest management, market information intelligence, storage, market finance, price fluctuation, etc. Even if the production technology is advanced, unless marketing is also improved simultaneously, efforts to increase the yield and production may go waste. It is learnt, efforts have been made to improve the marketing through enforcement of laws. However, these efforts were directed towards non perishable products like cereals and very limited efforts have been made in case of marketing of fruits in general and guava in particular.

The economics of guava production is indispensable since there is no proper farm business data on its cost of production. The accurate figures on establishment cost, operating cost and input requirements of guava orchard would be greatly helpful to the guava producers. This information will be of immense use to farm financing institutions.

Although, there are several factors affecting the productivity and production, but the most important factor is damage due to pest and disease, lack of irrigation facilities, lack of credit availability, lack of good seedling, desirable packaging of inputs/ pesticide, insecticide and unfavorable conditions a sound knowledge of the improved technology and full scale use of the recommended practices for successful results. The plantation of guava in Haryana does not produce an optimum yield due to neglect of orchards by the farmers and lack of proper scientific knowledge on its management. Researchers have amply established that adoptions of the recommended production technology are pre-requisite for obtaining higher productivity of any crop (Singh, 1998). Hence study on constraints of production and marketing of guava aspects may provide some guidelines about below objects.

- To study the production constraints of guava orchard in different district of Haryana

- To study the marketing constraints of guava orchard in different district of Haryana

\section{Methodology}

The present study was conducted in Hisar district, Hansi, Barwala Block, and Fatehabad district Bhuna, Fatehabad Block and Sirsa district Baraguda, Sirsa Block of Haryana which was selected purposively on basis of highest area and production under Guava cultivation. Further, Hisar, Fatehabad and Sirsa market were selected for the market study during 2011-2012. Finally 60 growers from randomly selected two blocks from each district were selected for the present study. On the basis of the nature of the data, budgeting technique and various economic tools were used for identify the constraints of production and marketing of guava. 


\section{Problems faced by the growers}

The information regarding problem faced by the producer in production of guava was also collected from the selected respondents.

\section{Constraints of production}

\section{Results and discussion}

Table 1 showed that the problem of damage due to unfavorable weather conditions was found maximum 19 farmers in Hisar district (95\%) where, it was lowest in the Fatehabad district faced by 17 farmers $(85 \%)$. Guava plants being tropical and subtropical cannot withstand extended cold periods. Temperature of $2^{\circ} \mathrm{C}$ to $0^{\circ} \mathrm{C}$ were injurious to the guava fruits if such low temperature prevail for longer period. Extremely high temperature and hot waves were also not conductive to the production of high quality of fruits. Under such conditions, the foliage was killed, much of the fruit drops and the exposed fruit became sunburned. The damage due to pest and diseases are maximum in Hisar faced by 16 farmers $(80 \%)$ and minimum in Fatehabad district faced by 14 farmers (70 \%). Lack of irrigation facilities was faced maximum in Hisar faced by 12 farmers (60 $\%)$ while minimum in Fatehabad district faced by 10 farmers (50\%). Lack of timely availability of credit most of the guava growers depend upon the private money lenders and market intermediaries for their credit requirement were maximum in Hisar faced by 15 farmers (75\%) and minimum in Fatehabad district 13 farmers (65\%) faced the problem of timely avalibility of credit. The good seedlings were prerequisites for successful establishment of an orchard. The quality seedling played an important role in increasing production and quality of fruits. The problem of lack of good seedling was maximum in Hisar faced by 17 farmers $(85 \%)$ while minimum in Fatehabad district faced by 15 farmers $(75 \%)$. Lack of desirable packaging of pesticides and insecticides created problems for farmers. If desirable size packaging was not available then their wastage takes place. This problem was maximum in Hisar faced by 12 farmers (55 percent) while, minimum in Fatehabad district faced by 10 farmers $(75 \%)$. The technical knowledge with respect to insect and pest, diseases, dose and type of pesticides and chemical fertilizers and various cultural operations maximum in Hisar faced by 18 farmers $(90 \%)$ while, minimum in Fatehabad district faced by 16 farmers $(80 \%)$. Lack of timely availability of fertilizer maximum in Hisar faced by 11 farmers (55\%) while, minimum in Fatehabad district faced by 9 farmers (45\%). These results got the support from the findings of Kameswara Rao (2000), Khunt et al. (2001), Nandal and Punia (2003) and More et al. (2008).

\subsubsection{Constraints in marketing of guava}

An informal discussion with the sample farmers revealed that with the marketing of guava they had lot of constraints (Table 2). Due to lack of minimum support price for guava, farmers fetch lower price for their produce during the seasonal gluts and in case when buyer join hands and constraints maximum in Sirsa faced by 20 farmers $(100 \%)$ while, minimum in Fatehabad district faced by 19 farmers $(95 \%)$. Lack of cooperative markets and facilities for direct selling were the another important problems which make farmers unable to get optimum prices for their produce and the constraints same in the study area. Payment of the produce delayed by the commission agent as farmers needs funds immediately for the farm activities. This problem was maximum in Hisar faced by 14 farmers (70 \%) while, minimum in Fatehabad district faced by 11 farmers (55 \%). Lack of competition among buyers during the peak season when arrival was very high then sometimes buyers acts join handed and offer less bid for the produce so farmers get less price for their produce. The constraints were maximum in Hisar faced by 16 farmers $\quad(80 \%)$ while minimum in Fatehabad district faced by 14 farmers $(70$ $\%)$. Due to inefficient market information and market intelligence farmers did not aware of the price fluctuation and market arrivals. The constraints maximum in Hisar faced by 14 farmers $(70 \%)$ while, minimum in Fatehabad district faced by 12 farmers $(60 \%)$. Lack of grading, packing plant and waxing and proper packing increased the shelf life of guava and it was transported easily and without loss in quality and quantity and grading helped in fetching higher prices for the produce according to grades. The constraints maximum in Hisar faced by 17 farmers $(85 \%)$ while, minimum in Fatehabad district faced by 15 farmers $(75 \%)$. Lacks of storage facilities due not have proper knowledge. The constraints maximum in Hisar faced by 18 farmers $(90 \%)$ while, minimum in Fatehabad district faced by 17 farmers $(75 \%)$. Lack of processing plant non-availability of processing facilities/plant also created lot of problem for the producers because in the open market they get very less price for their undersize produce as this can be utilize in juice plant and farmers may fetch fair prices for their undersize produce and the constraints maximum in Hisar faced by 18 farmers $(90 \%)$ while, minimum in Fatehabad district faced by 16 farmers $(80 \%)$. Lower prices due to seasonal gluts farmers fed that the price received by them for their produce during the peak period was not to the mark as deserved by them. The constraints maximum in Hisar faced by 19 farmers (95\%) while minimum in Fatehabad district faced by 17 farmers $(75 \%)$. Lack of stay arrangements and other basic amenities in the market creates a lot of problem for the farmers during their stay in the market for the marketing of their produce. The constraints maximum in Hisar faced by 15 farmers (75\%) while, minimum in Fatehabad district faced by 13 farmers $(65 \%)$. Malpractices in 
weighing is commonly practiced in the market and showed less quantity of produced by these practices and farmers fetch less revenue for their produce. This problem was maximum in Hisar faced by 16 farmers $(80 \%)$ while, minimum in Fatehabad district faced by 14 farmers $(70 \%)$. High marketing cost for per quintal of the produce was another common marketing problem faced by the guava growers and the constraints maximum in Hisar faced by 14 farmers (70 \%) while, minimum in Fatehabad district faced by 12 farmers (60\%). Similar findings were also reported by Sikka et al. (2005), Randev (2005), Saraswat et al. (2006) and Khunt et al. (2008).

Table 1: Constraints in production of guava fruit

\begin{tabular}{|c|c|c|c|c|c|}
\hline $\begin{array}{l}\text { Sr. } \\
\text { No. }\end{array}$ & Constraints & Hisar & Fatehabad & Sirsa & $\begin{array}{r}\text { Overall } \\
\text { Average }\end{array}$ \\
\hline 1 & $\begin{array}{l}\text { Damage due to unfavourable } \\
\text { weather condition }\end{array}$ & $\begin{array}{c}19 \\
(95.00)\end{array}$ & $\begin{array}{c}17 \\
(85.00)\end{array}$ & $\begin{array}{c}18 \\
(90.00)\end{array}$ & $\begin{array}{c}18 \\
(90.00)\end{array}$ \\
\hline 2 & Damage due to pest and disease & $\begin{array}{c}16 \\
(80.00)\end{array}$ & $\begin{array}{c}14 \\
(70.00)\end{array}$ & $\begin{array}{c}15 \\
(75.00)\end{array}$ & $\begin{array}{c}15 \\
(75.00)\end{array}$ \\
\hline 3 & Lack of irrigation facilities & $\begin{array}{c}12 \\
(60.00)\end{array}$ & $\begin{array}{c}10 \\
(50.00)\end{array}$ & $\begin{array}{c}11 \\
(55.00)\end{array}$ & $\begin{array}{c}13 \\
(65.00)\end{array}$ \\
\hline 4 & Lack of timely availability of credit & $\begin{array}{c}15 \\
(75.00)\end{array}$ & $\begin{array}{c}13 \\
(65.00)\end{array}$ & $\begin{array}{c}14 \\
(70.00)\end{array}$ & $\begin{array}{c}14 \\
(70.00)\end{array}$ \\
\hline 5 & Lack of good seedling & $\begin{array}{c}17 \\
(85.00)\end{array}$ & $\begin{array}{c}15 \\
(75.00)\end{array}$ & $\begin{array}{c}16 \\
(80.00)\end{array}$ & $\begin{array}{c}16 \\
(80.00)\end{array}$ \\
\hline 6 & $\begin{array}{l}\text { Lack of desirable packing of } \\
\text { pesticide and insecticides }\end{array}$ & $\begin{array}{c}12 \\
(60.00) \\
\end{array}$ & $\begin{array}{c}10 \\
(50.00)\end{array}$ & $\begin{array}{c}11 \\
(55.00) \\
\end{array}$ & $\begin{array}{c}11 \\
(65.00) \\
\end{array}$ \\
\hline 7 & Lack of technical knowledge & $\begin{array}{c}18 \\
(90.00)\end{array}$ & $\begin{array}{c}16 \\
(80.00)\end{array}$ & $\begin{array}{c}17 \\
(85.00)\end{array}$ & $\begin{array}{c}17 \\
(85.00)\end{array}$ \\
\hline 8 & $\begin{array}{l}\text { Lack of timely non-availability } \\
\text { of fertilizer }\end{array}$ & $\begin{array}{c}11 \\
(55.00)\end{array}$ & $\begin{array}{c}09 \\
(45.00)\end{array}$ & $\begin{array}{c}10 \\
(50.00) \\
\end{array}$ & $\begin{array}{c}10 \\
(50.00)\end{array}$ \\
\hline
\end{tabular}

Note: figures in parentheses indicate percentage to the number of growers in respective districts and to the total number of sample growers in the case of overall average.

Total Number of farmers selected were 60. (20 farmers were each district.)

Table 2: Constraints in marketing of guava fruit

\begin{tabular}{|c|c|c|c|c|c|}
\hline $\begin{array}{l}\text { Sr. } \\
\text { No. }\end{array}$ & Constraints & Hisar & Fatehabad & Sirsa & $\begin{array}{l}\text { Overall } \\
\text { average }\end{array}$ \\
\hline 1 & Lack of minimum support Price & $\begin{array}{c}20 \\
(100.00)\end{array}$ & $\begin{array}{c}19 \\
(95.00)\end{array}$ & $\begin{array}{c}19 \\
(95.00)\end{array}$ & $\begin{array}{c}19 \\
(95.00)\end{array}$ \\
\hline 2 & Lack of organization & $\begin{array}{c}19 \\
(95.00)\end{array}$ & $\begin{array}{c}19 \\
(95.00)\end{array}$ & $\begin{array}{c}19 \\
(95.00)\end{array}$ & $\begin{array}{c}19 \\
(95.00)\end{array}$ \\
\hline 3 & Delay in Payment & $\begin{array}{c}14 \\
(70.00)\end{array}$ & $\begin{array}{c}11 \\
(55.00)\end{array}$ & $\begin{array}{c}15 \\
(75.00)\end{array}$ & $\begin{array}{c}13 \\
(65.00)\end{array}$ \\
\hline 4 & Lack of competition among buyers & $\begin{array}{c}16 \\
(80.00)\end{array}$ & $\begin{array}{c}14 \\
(70.00)\end{array}$ & $\begin{array}{c}15 \\
(75.00)\end{array}$ & $\begin{array}{c}15 \\
(75.00)\end{array}$ \\
\hline 5 & Lack of market information & $\begin{array}{c}14 \\
(70.00)\end{array}$ & $\begin{array}{c}12 \\
(60.00)\end{array}$ & $\begin{array}{c}13 \\
(65.00)\end{array}$ & $\begin{array}{c}13 \\
(65.00)\end{array}$ \\
\hline 6 & $\begin{array}{l}\text { Lack of waxing, grading and packing } \\
\text { plant }\end{array}$ & $\begin{array}{c}17 \\
(85.00)\end{array}$ & $\begin{array}{c}15 \\
(75.00)\end{array}$ & $\begin{array}{c}16 \\
(80.00)\end{array}$ & $\begin{array}{c}16 \\
(80.00)\end{array}$ \\
\hline 7 & Lack of storage facility & $\begin{array}{c}19 \\
(95.00)\end{array}$ & $\begin{array}{c}17 \\
(85.00)\end{array}$ & $\begin{array}{c}18 \\
(90.00)\end{array}$ & $\begin{array}{c}18 \\
(90.00)\end{array}$ \\
\hline 8 & Lack of processing plant & $\begin{array}{c}18 \\
(90.00)\end{array}$ & $\begin{array}{c}16 \\
(80.00)\end{array}$ & $\begin{array}{c}17 \\
(85.00)\end{array}$ & $\begin{array}{c}17 \\
(85.00)\end{array}$ \\
\hline 9 & Lower prices due to seasonal gluts & $\begin{array}{c}19 \\
(95.00)\end{array}$ & $\begin{array}{c}17 \\
(85.00)\end{array}$ & $\begin{array}{c}18 \\
(90.00)\end{array}$ & $\begin{array}{c}16 \\
(80.00)\end{array}$ \\
\hline 10 & $\begin{array}{l}\text { Lack of stay arrangements in the } \\
\text { market }\end{array}$ & $\begin{array}{c}15 \\
(75.00)\end{array}$ & $\begin{array}{c}13 \\
(65.00)\end{array}$ & $\begin{array}{c}14 \\
(70.00)\end{array}$ & $\begin{array}{c}14 \\
(70.00)\end{array}$ \\
\hline 11 & Malpractices in weighing & $\begin{array}{c}16 \\
(80.00)\end{array}$ & $\begin{array}{c}14 \\
(70.00)\end{array}$ & $\begin{array}{c}15 \\
(75.00)\end{array}$ & $\begin{array}{c}15 \\
(75.00)\end{array}$ \\
\hline 12 & Higher marketing cost & $\begin{array}{c}14 \\
(70.00)\end{array}$ & $\begin{array}{c}12 \\
(60.00)\end{array}$ & $\begin{array}{c}13 \\
(65.00)\end{array}$ & $\begin{array}{c}13 \\
(65.00)\end{array}$ \\
\hline
\end{tabular}

Note: Figures in parentheses indicate percentage to number of growers in respective districts and to the total number of sample growers in the case of overall average farms.

Total Number of farmers selected were 60. (20 farmers were each district.)

\section{Reference}

[1]. Anonymous 2010. Haryana Horticulture Database. Directorate of Horticulture, Haryana.

[2]. Kameswara Rao, G. (2000). Comparative economics of banana and sugarcane cultivation in Tungabhadra command area of Karnataka. M.Sc. (Agri) Thesis, Univ. Agric. Sci., Dharwad (India)

[3]. Khunt, K. A. , Gargipara, H.M. and Gadhvi, B.K. (2001). Marketing of Keshra Mango in Saurashtra region of Gujarat state. Ind. J. Agril. Mktg. 15(1): 47-54. 
[4]. Khunt, K.A., Vekariya, S.B. and Gajipara H.M. (2008). Performance and problems of Regulated Markets in Gujarat. Ind. J. Agril. Mktg. 22(1): 82-98.

[5]. Kumar, B., Mistry, N.C., Singh, B. and Gandhi, C.P. (2010). Indian Horticulture Database National Horticulture Board, Gurgaon. pp. 79-81.

[6]. More, S.S., Mangave, K.K. and Kalalbandi, B.M. (2008). Constraints faced by banana growers in production marketing and finance of banana cultivation. International J. Agri. Sci. 4(2): 562-564.

[7]. Nandal, R.S. and Punia, Deep. (2003). A study on economics of major vegeTable and fruit crop in Haryana state. Research Bulletin, Department of Agricultural Economics CCS HAU, Hisar. Res. Bulletin. No.: 50.

[8]. Randev, A. K. (2005). Marketing of Apple in Shimla district of Himachal Pradesh-India. Ind. J. Agril. Mktg. 19(3): 11-19.

[9]. Saraswat, S.P., Dahiya, P. S. and Singh, P., (2006). Production and Marketing of Peach Fruit: A Case Study of Rajgarh Area of District Sirmour in Himachal Pradesh. Ind. J. Agril. Mktg. 20(2): 81-91.

[10]. Sikka, B.K., Sharma, M.L. and Jairath, M.S. (2005). Managing Marketing Problems and Emerging Needs of Apple Growers of Uttaranchal. Ind. J. Agril. Mktg. 19(2): 238-248.

[11]. Singh, B. (1998). Adoption of improved practices of Kinnow in Haryana. M.Sc. thesis CCSHAU, Hisar. 